\title{
ASTRONOMICAL AND GEODETIC ASPECTS OF THE LOCATION OF SACRED BUILDINGS IN KRAKOW
}

\author{
AGH University of Science and Technology;
}

Keywords: Krakus Mound, Krakow churches and monasteries, sunrise and sunset, solar calendar.

\begin{abstract}
The location of a significant number of Krakow churches and monasteries marks the lines which have the character of an astronomical calendar. Two lines are described that correspond closely to the direction of Krakus Mound - Wanda Mound. Advantageous conditions have been demonstrated in astronomical aspects, with the location of the following churches: St. Benedict's, St. Adalbert's on the Main Square, St. Mary's and the Esterka Mound. Described in detail are: sunset line on the summer solstice day on the background of Wawel Hill and two meridian lines.
\end{abstract}

\section{ASTRONOMICZNE I GEODEZYJNE ASPEKTY LOKALIZACJI BUDOWLI SAKRALNYCH KRAKOWA}

Słowa kluczowe: kopiec Krakusa, kościoły i klasztory krakowskie, wschody i zachody Słońca, kalendarz solarny.

\begin{abstract}
Abstrakt
Lokalizacja znacznej liczby kościołów i klasztorów krakowskich wyznacza linie o charakterze astronomiczno-kalendarzowym. Opisano dwie linie, które są ściśle związane z kierunkiem kopiec Krakusa - kopiec Wandy. Wykazano korzystne warunki, w aspekcie astronomicznym lokalizacji: kościoła św. Benedykta, kościoła św. Wojciecha na Rynku Głównym, kościoła Mariackiego oraz kopca Esterki. Szczegółowo opisano linię kierunku zachodu Słońca w dniu przesilenia letniego na tle Wzgórza Wawelskiego oraz dwie linie południkowe.
\end{abstract}

\section{INTRODUCTION}

The location of the Mounds of Krakus (KK) and Wanda (KW) and many sacred buildings (monasteries and churches) of Krakow defines interesting astronomical-calendar lines. The KK-KW line, as a result of the annual movement of the Sun, sets two dates (around 1st May and around 12th August) of the sunrise towards $\mathrm{KW}_{1}$ and sunset towards $\mathrm{KW}_{2}$ (Fig. 1). On 4th November and 6th February, a person standing on the top of Krakus Mound observes the sunrise towards $\mathrm{KW}_{3}$ and sunset towards $\mathrm{KW}_{4}$ (Kozubica in the Podgórki Tynieckie range). An observer located on Wanda Mound observes the sunset over Krakus Mound on those days. A significant number of (especially the old ones) Krakow monasteries and churches were built along the lines marking the directions of sunrise or sunset on the summer and winter solstice (green lines in Fig. 1). Many churches are also located along the north-south and east-west lines. In addition, in the area of Krakow there are monasteries and churches built along a line parallel to the $\mathrm{KW}_{1}$ line (KK $-\mathrm{KW}$ and to the $\mathrm{KW}_{2}$ line (Fig. 1). Sunrise and sunset in the directions given in Fig. 1 show eight dates, dividing approximately one year into eight 


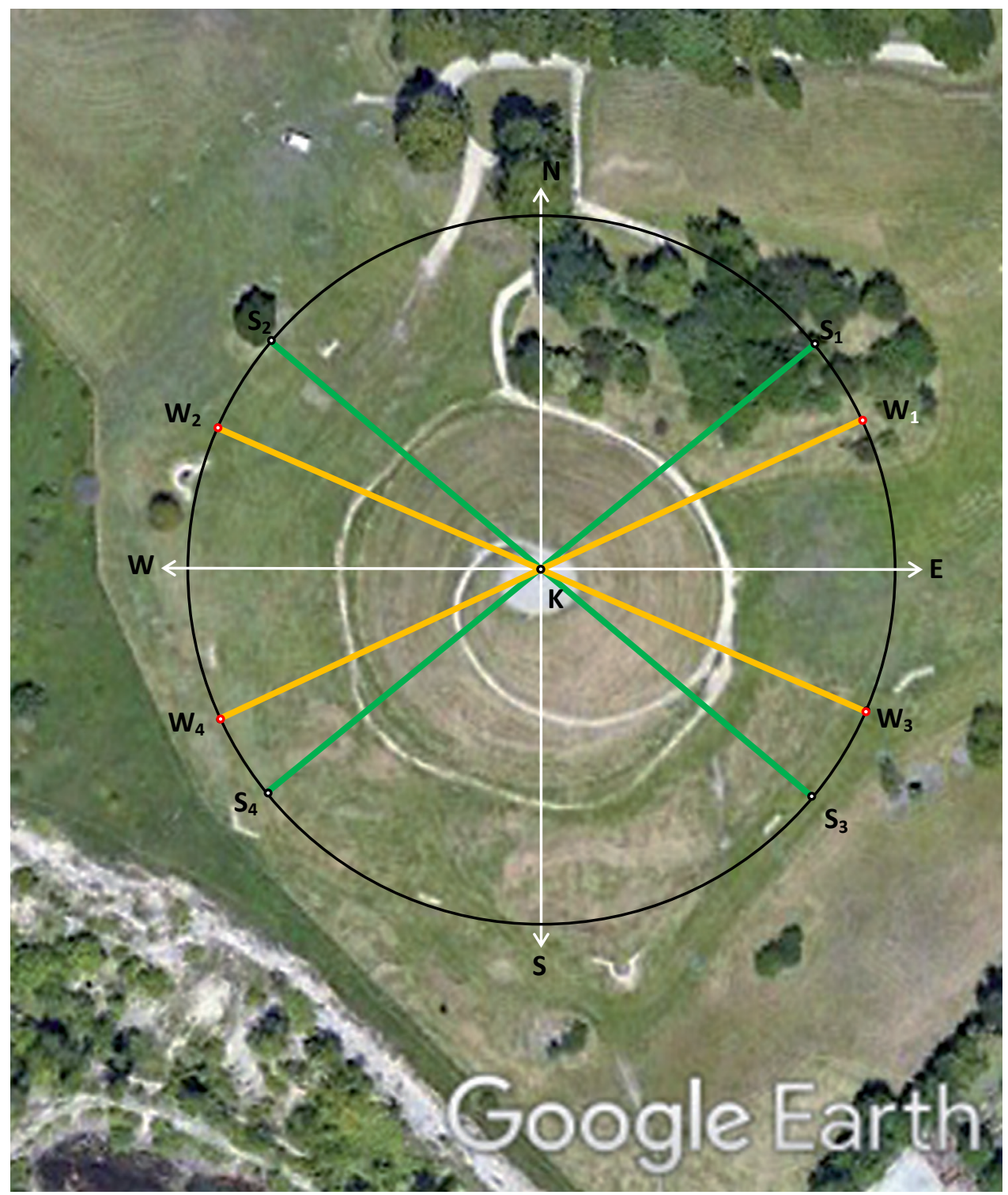

Fig. 1. Sunrise and sunset directions observed on Krakus Mound. Axis of the mound - K. Prepared by: W. Góral, B. Skorupa using Google Earth

Rys. 1. Kierunki wschodu i zachodu Słońca obserwowane na kopcu Krakusa. Oś kopca - K. Opracowanie: W. Góral, B. Skorupa za pomocą Google Earth

equal parts. The division of the year into eight parts was known in Central Europe as early as the Neolithic period. The considered lines are geodetic lines connecting two points on the surface of the current reference ellipsoid (Earth mathematical model) WGS84. The output data for calculating the length of the line and its bearing are geographic (geodetic) coordinates. The precise coordinates of seven high towers in the Krakow area, with the accuracy of $0.01 \mathrm{~m}$, are shown in Table 1 (Skoru- pa B., 1997). These coordinates were determined by Andrzej Janeczek and Bogdan Skorupa in 1995, graduates of the Faculty of Mine Surveying and Environmental Engineering (WGGiIŚ), AGH-UST. For this purpose, geodetic GPS signal receivers and a precise theodolite were used. Angular measurements aimed at the center of the sphere were located in the apex part of the tower of the given church. The coordinates of other churches were determined on the basis of the Google Earth inter- 
Table 1. Geodetic coordinates of seven Krakow's towers

Tabela 1. Współrzędne geodezyjne siedmiu wież krakowskich

\begin{tabular}{|l|l|l|}
\hline \multicolumn{1}{|c|}{ Point designation (abbreviation) } & Latitude $(\varphi)$ & Longitude $(\lambda)$ \\
\hline St. Anna's Church (KA) & $50^{\circ} 03^{\prime} 44,85594^{\prime \prime}$ & $19^{\circ} 56^{\prime} 00.95422^{\prime \prime}$ \\
\hline St. Mary's Church (KM) & $50^{\circ} 03^{\prime} 42,21901^{\prime \prime}$ & $19^{\circ} 56^{\prime} 20.37136^{\prime \prime}$ \\
\hline St. Peter and Paul Church (KPiP) & $50^{\circ} 03^{\prime} 24,92028^{\prime \prime}$ & $19^{\circ} 56^{\prime} 20.83024^{\prime \prime}$ \\
\hline Jesuit Church (KJ) & $50^{\circ} 03^{\prime} 42,85752^{\prime \prime}$ & $19^{\circ} 56^{\prime} 54.92374^{\prime \prime}$ \\
\hline Town Hall Tower (WR) & $50^{\circ} 03^{\prime} 41,30007^{\prime \prime}$ & $19^{\circ} 56^{\prime} 11.11769^{\prime \prime}$ \\
\hline Clock Tower (WZe) & $50^{\circ} 03^{\prime} 17,01946^{\prime \prime}$ & $19^{\circ} 56^{\prime} 06.39912^{\prime \prime}$ \\
\hline Sigmund Tower (WZy) & $50^{\circ} 03^{\prime} 17,66150^{\prime \prime}$ & $19^{\circ} 56^{\prime} 08.18956^{\prime \prime}$ \\
\hline
\end{tabular}

net map. They were related to the base of a given church tower and the accuracy of their determination was estimated at about $3 \mathrm{~m}$. On the maps of "Google Earth" the course of the presented lines is also marked. By means of the known coordinates of the two points, as a result of solving the so-called reverse geodetic task, the length and azimuth of the given direction were calculated. In the considered case, the azimuth of the sunrise from Krakus Mound towards Wanda Mound is known as $\mathrm{KW}_{1}\left(65^{\circ} 30^{\prime}\right)$, (Fig. 1). To shorten the record, for each direction discussed, the value of its azimuth, referred to Krakus Mound, is given in brackets. Around 1st May and 12th August, the sunset seen from Krakus Mound will take place in the direction of $\mathrm{KW}_{2}\left(294^{\circ} 30^{\prime}\right)$. The opposite of the above direction sets the direction of the sunrise of $\mathrm{KW}_{3}\left(114^{\circ} 30^{\prime}\right)$, which takes place around 4th November and around 6th February. In turn, during these days the sunset seen from the Krakus Mound is observed in the direction of the $\mathrm{KW}_{4}\left(245^{\circ} 30^{\prime}\right)$ line. All four directions of sunrise and sunset are marked in yellow, (Fig. 1). In the paper (Góral, 2018), most of the above-mentioned directions of sunrises and sunsets are described in detail. These directions are characterized by well visible hollows or hills on the horizon. Green lines indicate the direction of sunrise and sunset on the summer solstice $\mathrm{KS}_{1}\left(50^{\circ} 57^{\prime}, 51^{\circ} 46^{\prime}\right)$ and $\mathrm{KS}_{2}\left(308^{\circ} 14^{\prime}, 309^{\circ} 04^{\prime}\right)$. In turn, $\mathrm{KS}_{3}\left(127^{\circ} 29^{\prime}, 128^{\circ} 14^{\prime}\right)$ and $\mathrm{KS}_{4}\left(231^{\circ} 46^{\prime}, 232^{\circ} 31^{\prime}\right)$ indicate the direction of sunrise and sunset on the winter solstice, Fig. 1. For individual directions, azimuth values are given in brackets related to the range in which the rising Sun shifts along the horizon from the moment of contact of the upper part of the sun disc to the moment of contact of its lower part. In turn, we observe the sunset from the moment of contact of the lower part of the sun disc to the contact of the upper part with the horizon line. When calculating the azimuth of sunrise and sunset, the observed value of the angular radius of the solar disk (16') and the standard value of atmospheric refraction over the horizon $\left(35^{\prime}\right)$ are taken into account. This value is slightly larger than the observed horizontal angular diameter of the solar disk, whose value is about $32^{\prime}$. When the moment of sunrise is related to the contact of the upper part of the solar disk with the horizon line, then the zenithal distance of the Sun is $z=90^{\circ} 51^{\prime}$. In fact, the phenomenon of the sunrise or sunset of a given celestial body is observed on visual horizon line (the boundary of the topography of the terrain and the sky). For an observer on the western side of Krakus Mound, the horizon is on a horizontal height roughly $20^{\prime}$. We assume that at the moment of sunrise (sunset) the zenith distance of the center of the sun disk is $\mathrm{z}=90^{\circ}$, which corresponds to the horizontal height $\mathrm{h}=0^{\circ}$. Considering the correction of refraction in these conditions, the angular radius of the sun disk and the height of the skyline above the horizon make the lower part of the sun disk touching the visual horizon.

\section{ST. SEBASTIAN'S CHURCH (SE) - CAMALDOLESE CHURCH (KKa) LINE}

At a distance of $10262 \mathrm{~m}$ south of Wanda Mound $(\mathrm{KW})$ on the northern slope of Wieliczka there is a wooden St. Sebastian's Church $\left(49^{\circ} 58^{\prime} 40^{\prime \prime} 8,20^{\circ} 03^{\prime} 57^{\prime \prime} 6\right.$, $\mathrm{Se})$, Fig. 2. The bearing $\mathrm{Se}-\mathrm{KW}$ is $48^{\prime} 38^{\prime \prime}$. St. Sebastian's Church is located very close (about 140 m west) to the meridian of Wanda Mound. The distance between St. Sebastian's Church (Se) and Krakus Mound (KK) is $10204 \mathrm{~m}$ long. The bearing of KK - Se line is $130^{\circ} 53^{\prime}$. 


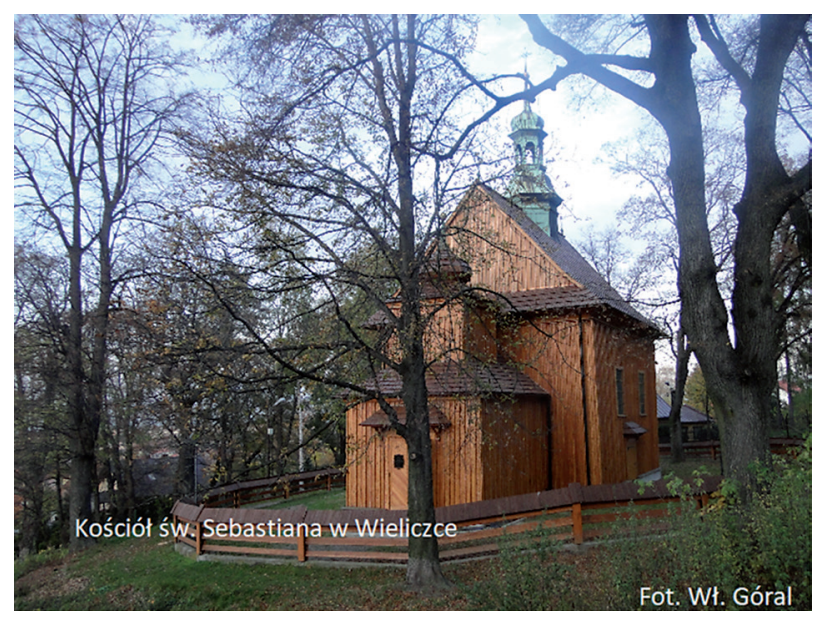

Fig. 2. St. Sebastian's Church in Wieliczka

Rys. 2. Kościół św. Sebastiana w Wieliczce

The observer located on Krakus Mound can observe the sunrise in the direction of $\mathrm{KK}-\mathrm{Se}$ on the horizon of Bukowa Mountain for several days around winter solstice. Comparing the distances of $\mathrm{Kr}-\mathrm{Se}$ and Se-KW we can see that the difference is $58 \mathrm{~m}$. The distance between Wanda Mound and Krakus Mound is 8630 $\mathrm{m}$. We can see that the triangle with the tops $\mathrm{KK}, \mathrm{KW}$, Se is close to isosceles. In addition, it is worth noting that the azimuth of the bisector of the angle between $\mathrm{KK}-\mathrm{N}$ direction and the KK-Se direction is $65^{\circ} 26^{\prime}$, i.e. its value is $4^{\prime}$ lower than the value of $\mathrm{KK}-\mathrm{KW}$ direction azimuth. This observation could have formerly been of great practical importance while using the calendar based on the division of the year into eight parts, be-

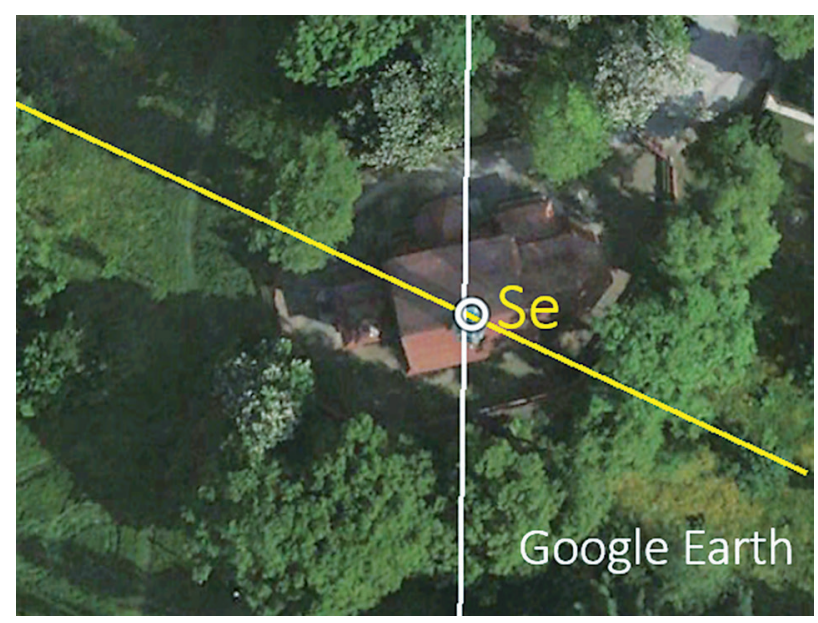

Fig. 4. St. Sebastian's Church aerial view Rys. 4. Kościół św. Sebastiana w Wieliczce - Se

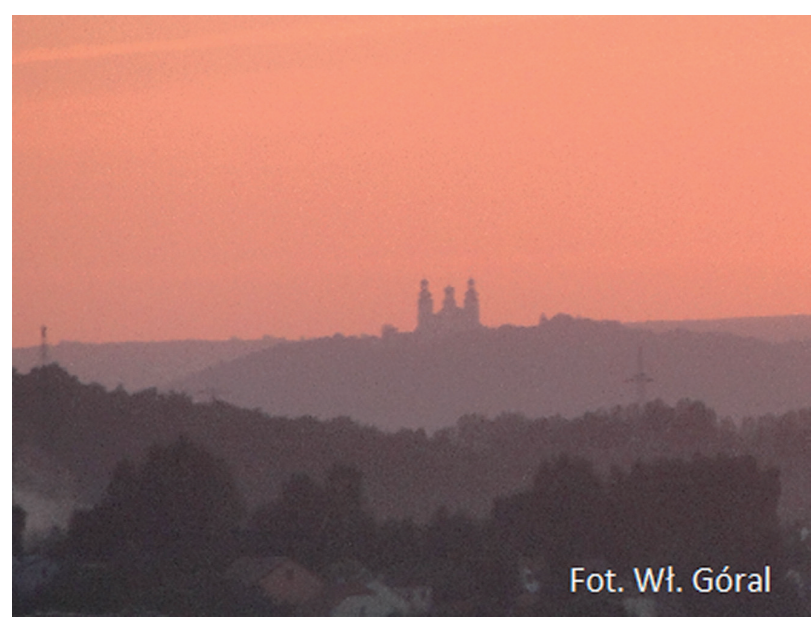

Fig. 3. View of the Camaldolese Church from St. Sebastian's Church

Rys. 3. Widok na kościół Kamedułów spod kościoła św. Sebastiana

cause the north direction determined at a given location and the direction of sunrise on the day of the winter solstice enabled the determination of a direction parallel to the direction KK - KW. St. Sebastian's church is surrounded by tall trees, but on its west side there is a beautiful panorama on the horizon with Camaldolese Church $\left(50^{\circ} 02^{\prime} 45^{\prime \prime} 1,1^{\circ} 50^{\prime} 25^{\prime \prime} 9\right.$, KKa), Fig. 3 . The distance between churches is $17835 \mathrm{~m}$. Azimuth direction $\mathrm{Se}-\mathrm{KK}$ is $295^{\circ} 07^{\prime}$. This value differs by 37 minute of arc from the azimuth direction $\mathrm{KW}_{2}$ $\left(294^{\circ} 30^{\prime}\right)$, Fig. 1. In practice, this means that the observer located next to St. Sebastian's Church in Wiel-

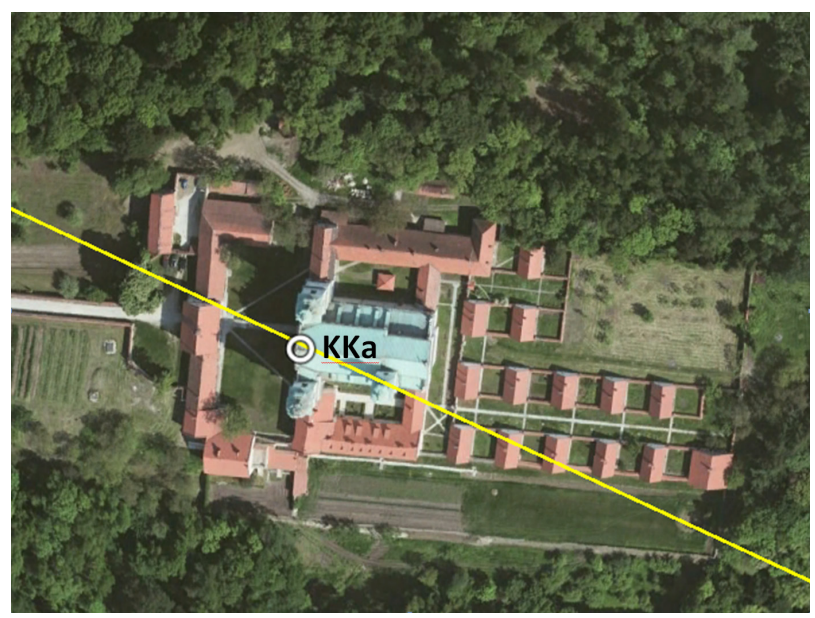

Fig. 5. The Camaldolese Church and Monastery

Ryc. 5. Kościół i klasztor Kamedułów - KKa 
iczka will observe around 1st May and 12th August sunset behind Camaldolese Church on the horizon of the Wolski Forest. The course of the line against the background of both churches is marked in yellow, Fig. 4, Fig. 5.

\section{BENEDICTINE CHURCH (KB) - DOMINICAN CHURCH (KD) LINE}

The KB - KD line is defined by the location of the Benedictine Church (5001'08.7", 1948'07.3", KB) of the Abbey in Tyniec, Fig. 6, and the location of St. Dominican's Church $\left(50^{\circ} 03^{\prime} 33.8^{\prime \prime}, 19^{\circ} 56^{\prime} 22.6^{\prime \prime}, \mathrm{KD}\right)$, Fig. 7. The Dominican's Church is $10826 \mathrm{~m}$ from the starting point $(\mathrm{KB})$, while the azimuth of the KB-KD line is $65^{\circ} 29^{\prime}$. The calculated azimuth value of the $\mathrm{KB}$ - KD direction is surprising because it differs from the azimuth direction of Krakus Mound - Wanda Mound $\left(\mathrm{KW}_{1}\right.$, Fig. 1) by only one angular minute. It turns out that this line crosses the buildings of the Norbertine Monastery on Salwator (KN) at a distance of $8876 \mathrm{~m}$., Fig. 8. In addition, on the extension of the KB-KD line towards NE, it runs near the Jesuit Church located in the Kopernika Street at a distance of $11531 \mathrm{~m}$ from KB. Further on, this line runs along the Kopernika Street next to the building of the former Astronomical Observatory. Its extension at a distance of $17849 \mathrm{~m}$ from KB crosses the Church of Our Lady the Queen of Poland The Lord's Ark (5005'06.36", 2001'45.46"), Fig. 9, in Nowa Huta.

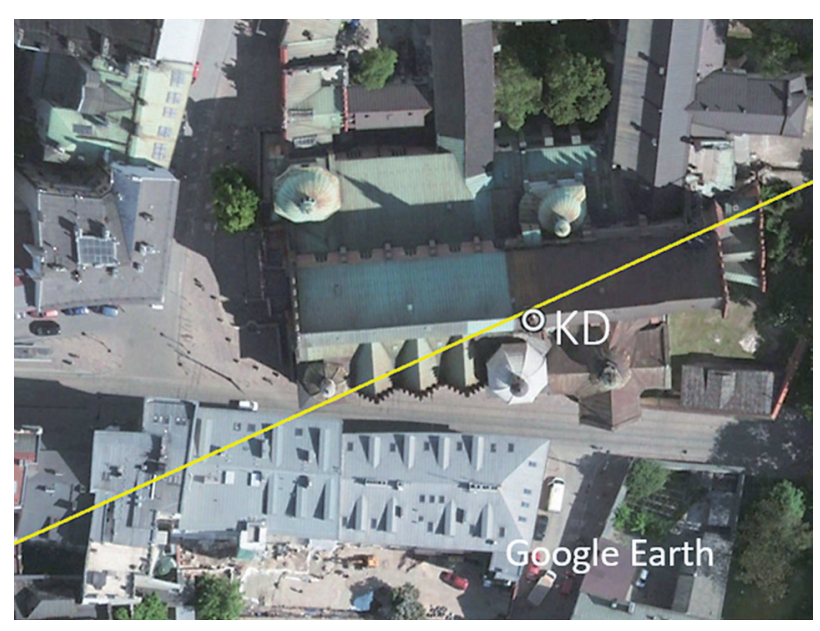

Fig. 7. Dominican Church aerial view

Rys. 7. Kościół i klasztor Dominikanów - KD

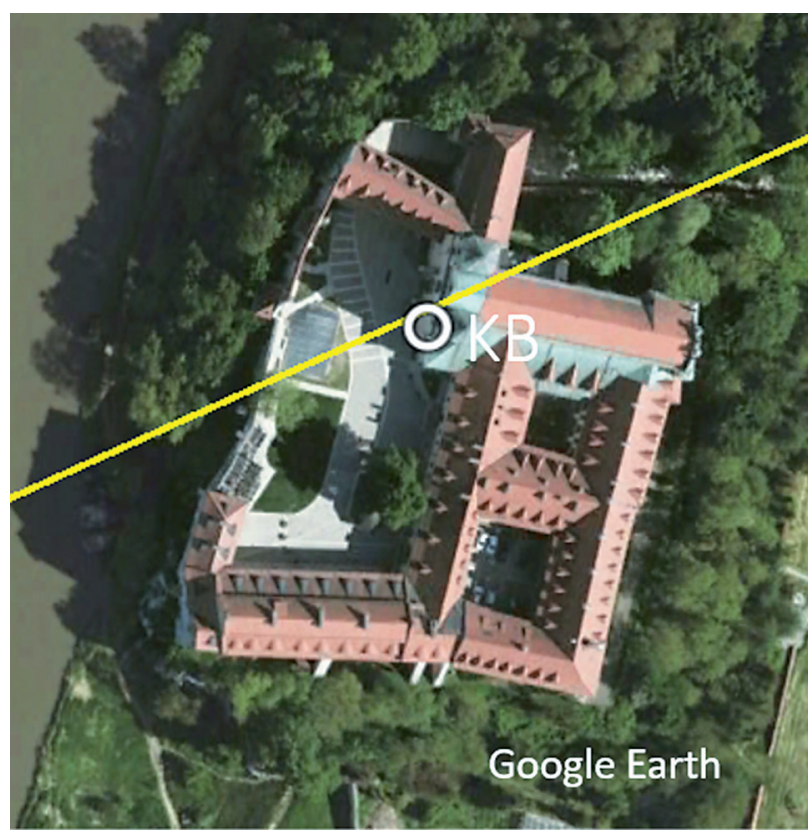

Fig. 6. Benedictine Church and Monastery at Tyniec, aerial view

Rys. 6. Kościół i klasztor Opactwa Benedyktynów w Tyń$\mathrm{cu}-\mathrm{KB}$

In any point of this line, in the direction of $\mathrm{KB}-$ $\mathrm{KD}$ - AP, we can watch the sunrise approximately on 1st May and approximately on 12th August. In the opposite direction AP - KD - KB we can watch the sunset around 6th February and around 4th November. The yellow line on this temple intersects with the green line indicating the direction of sunrise on the summer

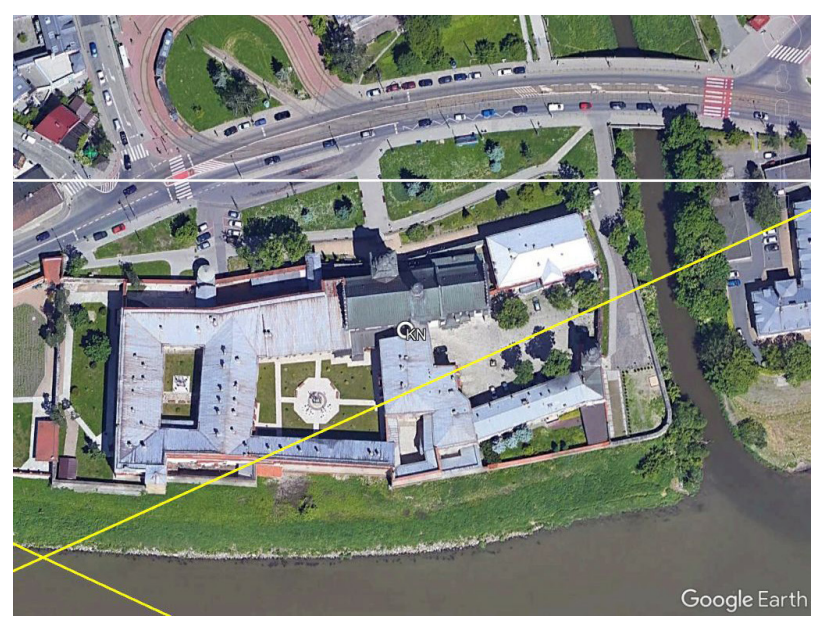

Fig. 8. Monastery of the Norbertines

Rys. 8. Klasztor Sióstr Norbertanek - KN 


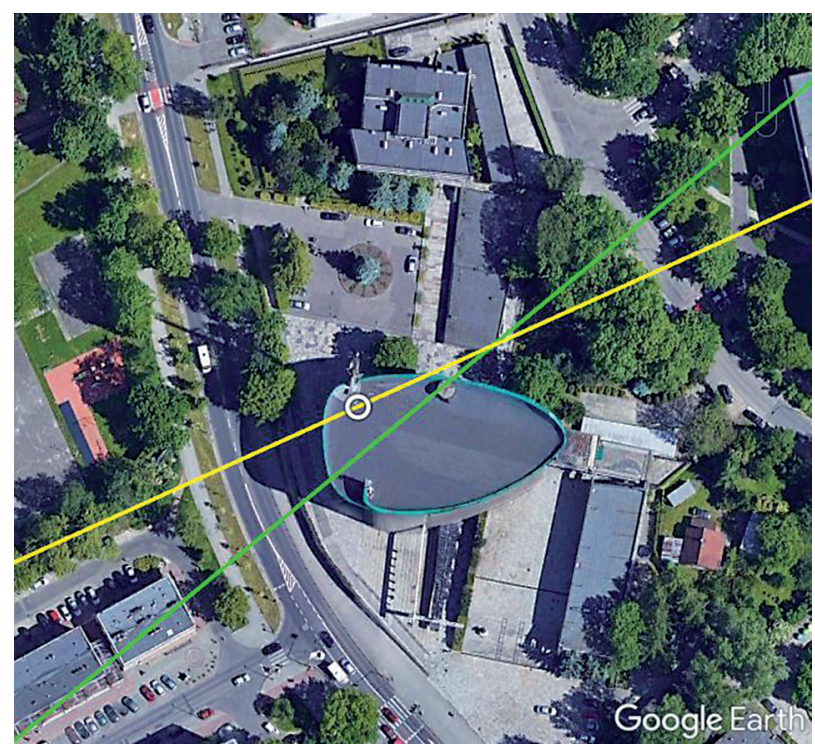

Fig. 9. The Lord's Ark, aerial view

Rys. 9. Kościół Matki Bożej Królowej Polski (Arka Pana $-\mathrm{AP})$

solstice. It is an extension of the line defined by the location of the Redemptorist Church and St. Joseph's Church in Podgórze.

\section{ST. BENEDICT'S (BE) - ST. ANTONYS CHURCH (AN) LINE}

Near Krakus Mound St. Benedict's Church is located, $\left(50^{\circ} 02^{\prime} 35.78^{\prime \prime}, 19^{\circ} 57^{\prime} 25.90^{\prime \prime}\right)$. The main axes of the church set the direction east - west and south north, Fig. 10. A few dozen years ago, one could admire the beautiful panorama of Krakow and observe above the Wawel Hill summer solstice sunset, Fig. 11. Nowadays the church is surrounded on all sides by lush bushes and trees. An observer from the church has the impression that it is in a forest a clearing and not near the center of Krakow, Fig. 13 and Fig. 14, and in the photo from a bird's eye view in Fig. 15. From St. Benedict,s Church starts the line summer solstice sunset, which in turn runs through the churches: Corpus Christi (5002'59.36", 1956'41.43), Fig. 16, St. Bernardine's Church, $\left(50^{\circ} 03^{\prime} 17.06^{\prime \prime}, 19^{\circ} 56^{\prime} 08.10^{\prime \prime}\right)$, Wawel Cathedral $\left(50^{\circ} 03^{\prime} 17.06^{\prime \prime}, 19^{\circ} 56^{\prime} 08.10^{\prime \prime}\right)$, Fig. 17 and St. Anthony's Church in Bronowice Małe (50 05'13.87", $\left.19^{\circ} 52^{\prime} 27.84^{\prime \prime}\right)$, Fig. 18. In addition, this line runs near the church St. John Cantius at Bronowice Małe. The azimuth value of this line is $309^{\circ} 31^{\prime}$ and is virtually

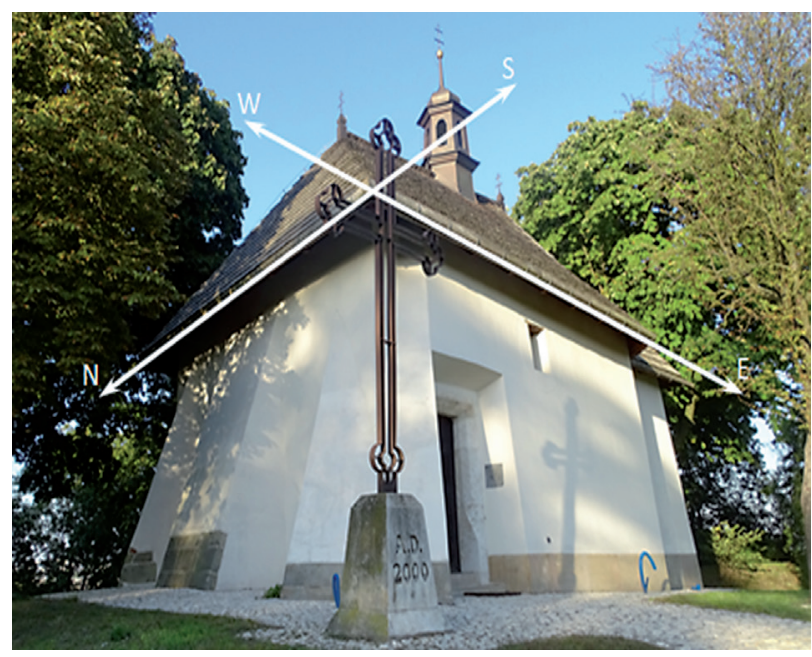

Fig. 10. St. Benedict's Church - Be, Photo: W. Góral Rys. 10. Kościół św. Benedykta - Be. Fot. W. Góral

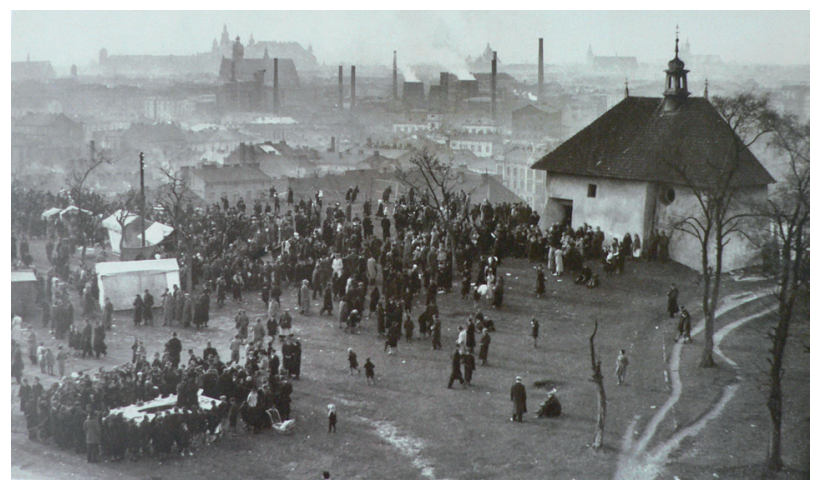

Fig. 11. St. Benedict Church, 1938

Rys. 11. Kościół św. Benedykta, 1938

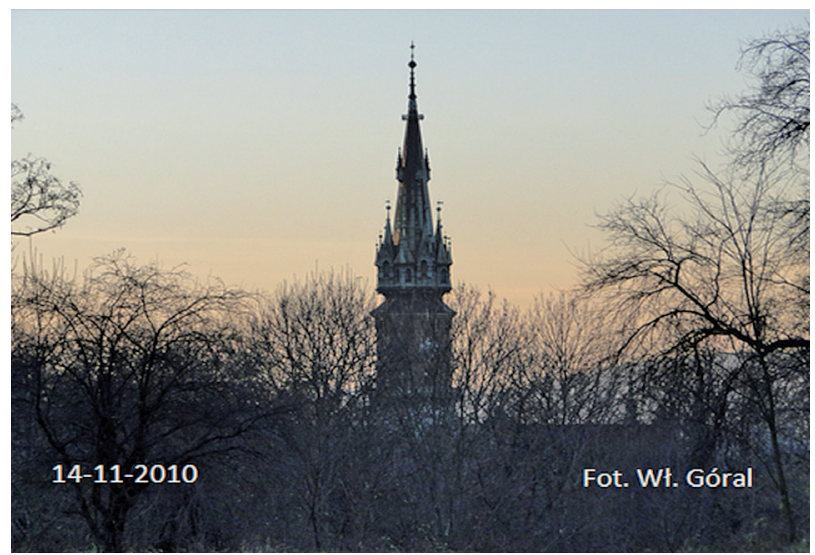

Fig. 12. View from St. Benedict's Church to the tower of the of St. Joseph's Church

Rys. 12. Widok z kościoła św. Benedykta na wieżę kościoła św. Józefa 


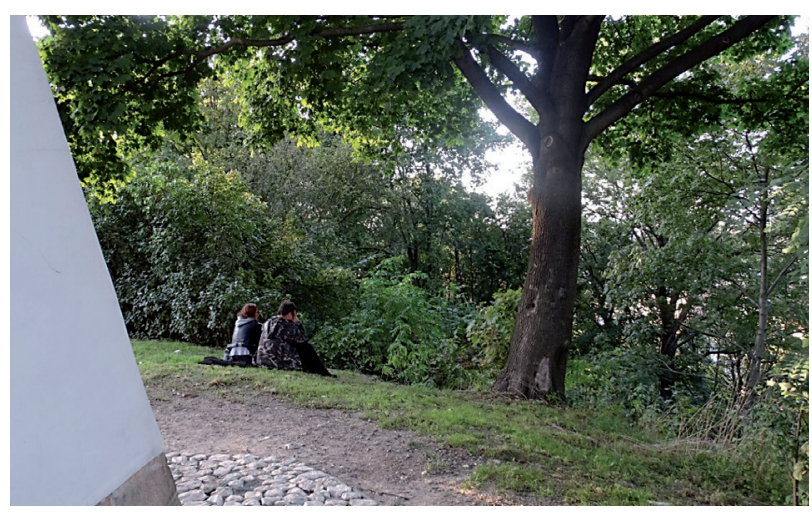

Fig. 13. View towards Krakow, summer 2019 Rys. 13. Widok w kierunku Krakowa, lato 2019

Fot. 13. W. Góral

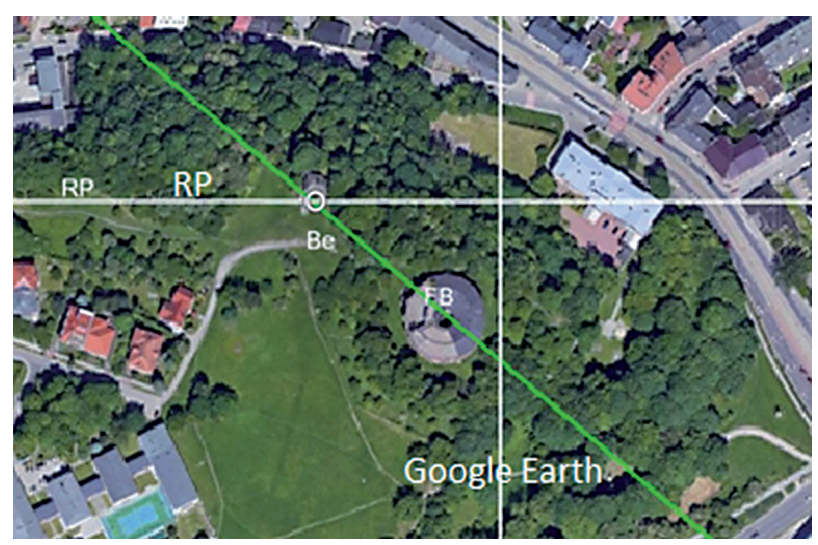

Fig. 15. St. Benedict's Church, aerial view - Be Benedict's Fort - FB

Rys. 15. Kościół św. Benedykta -Be, Fort Benedykta - FB

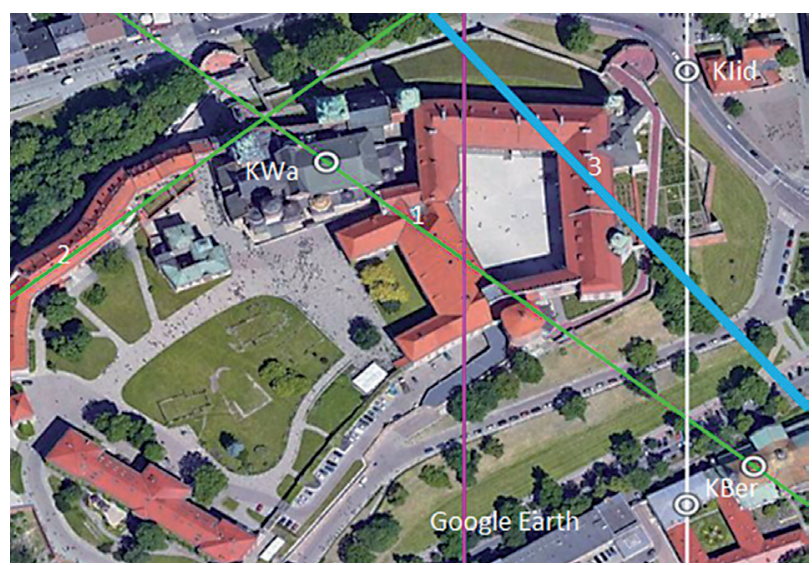

Fig. 17. Bernardine Church - KBer Wawel Cathedral - Kwa Rys. 17. Kościół Bernardynów - KBer, Katedra Wawelska - Kwa

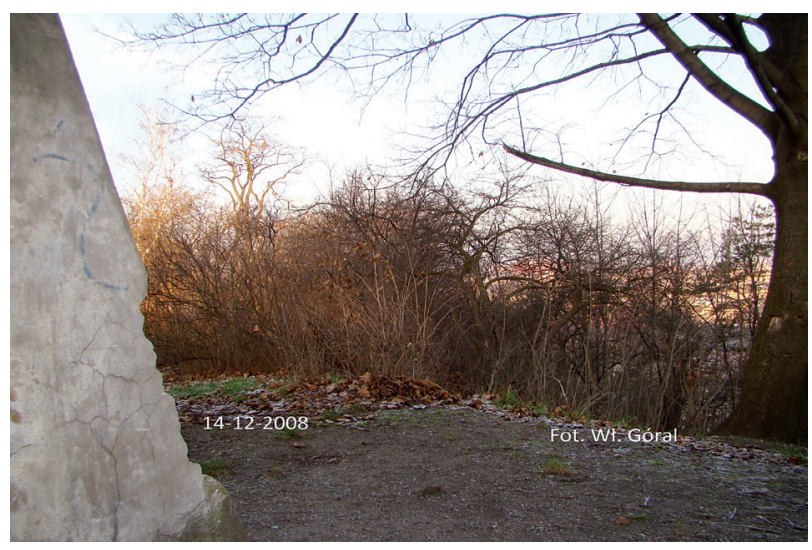

Fig. 14. View towards Krakow, winter 2008

Rys. 14. Widok w kierunku Krakowa, zima 2008

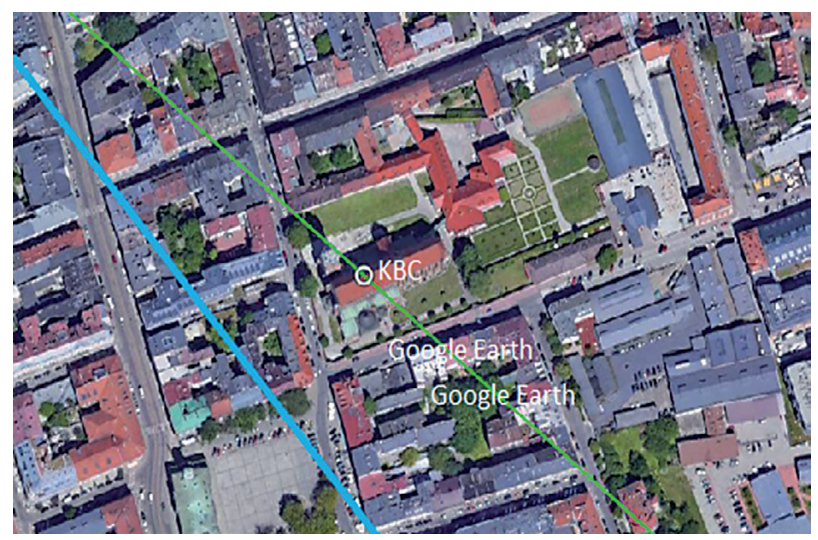

Fig. 16. Church of Corpus Christi, aerial view - KBC

Rys. 16. Kościół Bożego Ciała z lotu ptaka - KBC

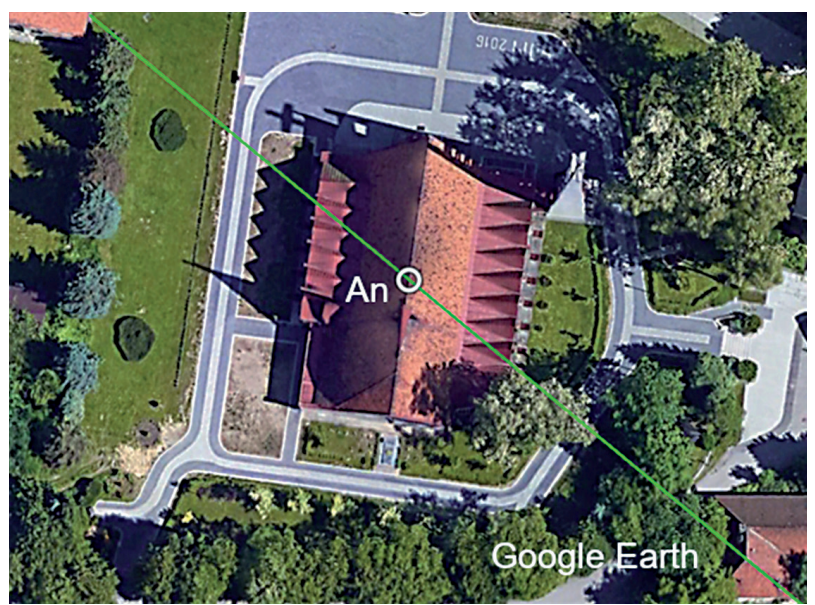

Fig. 18. St. Anthony's Church - An

Rys. 18. Kościół św. Antoniego - An 
consistent with the azimuth value of direction $\mathrm{KS}_{2}$, Fig. 1. In Fig. 15 one can see that the extension of the line in the opposite direction, $\mathrm{Be}-\mathrm{An}$ passes through the center of Fort St. Benedict.

\section{ASTRONOMICAL ASPECTS OF ST. MARY'S CHURCH}

In the center of Krakow, the bugler located on the left Tower of St. Mary's Church - KM, has best conditions for observing sunrises and sunsets during the year. Most astronomical and calendar lines focus here. St. Mary's Church faces East. On its southern wall there is a sundial showing the local apparent time. Sunrise during the summer solstice is in the direction of the Discalced Carmelite Church Rakowicka Street

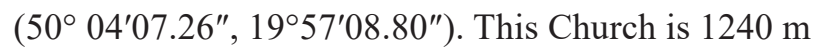
from St. Mary's Church. The azimuth value of this direction is $50^{\circ} 31^{\prime}$.

In turn the bugler watches sunrise during the winter solstice towards the church at Biskupice ( $49^{\circ} 57^{\prime} 56.77^{\prime \prime}$, $\left.20^{\circ} 07^{\prime} 04.35^{\prime \prime}\right)$, located at a distance of $16670 \mathrm{~m}$. The

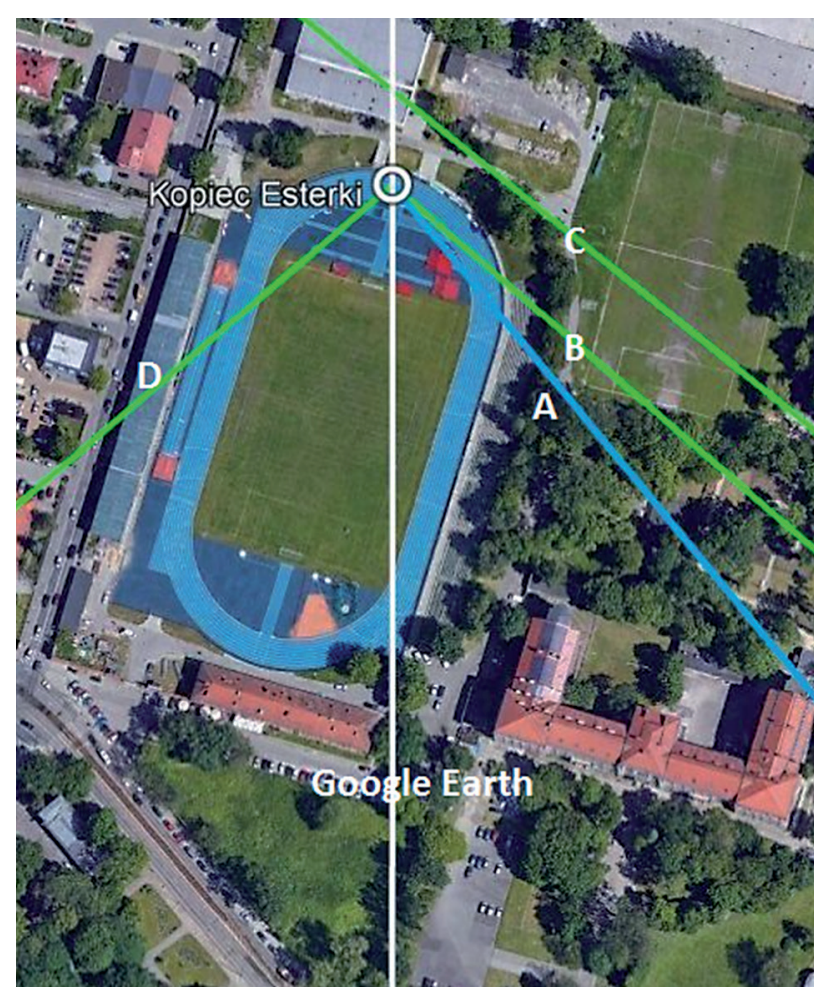

Fig. 19. Localization of Esterka Mound - KE (By W. Góral, J. Kudrys)

Rys. 19. Lokalizacja Kopca Esterki - KE azimuth of this line is $129^{\circ} 41^{\prime}$. On the parallel line at a distance of $690 \mathrm{~m}$ from St. Mary's Church, Jesuit Church in Kopernika Street is located. In turn, on the meridian line (right side of Fig. 20 ) at a distance of $530 \mathrm{~m}$ there is a Church of Saints Peter \& Paul in Grodzka Street.

The sunset line during the summer solstice day faces the St. Francis of Assisi Church (50 05'30.34", $\left.19^{\circ} 52^{\prime} 50.72^{\prime \prime}\right)$ in Bronowice Wielkie. The azimuth of this direction is $308^{\circ} 44^{\prime}$. In addition, the line runs north to the location of Esterka Mound-KE, (Fig. 19, line C). The green line $\mathrm{B}$ indicates the direction from Esterka Mound towards the sunrise during the winter solstice day over St. Adalbert's Church - Wo (5003'39.24",1956'15.78"), located in the Main Square (Fig. 20). The location of St. Adalbert's Church is indicated by the sunset line on the winter solstice led out of the tower of St. Mary's Basilica. The Esterka Mound (5004'38.5", 1954'28.9"), (Banasik, 2010) was located in the former garden of the royal residence at Łobzów. From the location of this mound one could admire the view of old Krakow, including the clearly visible Wawel Hill. The Esterka Mound was de-

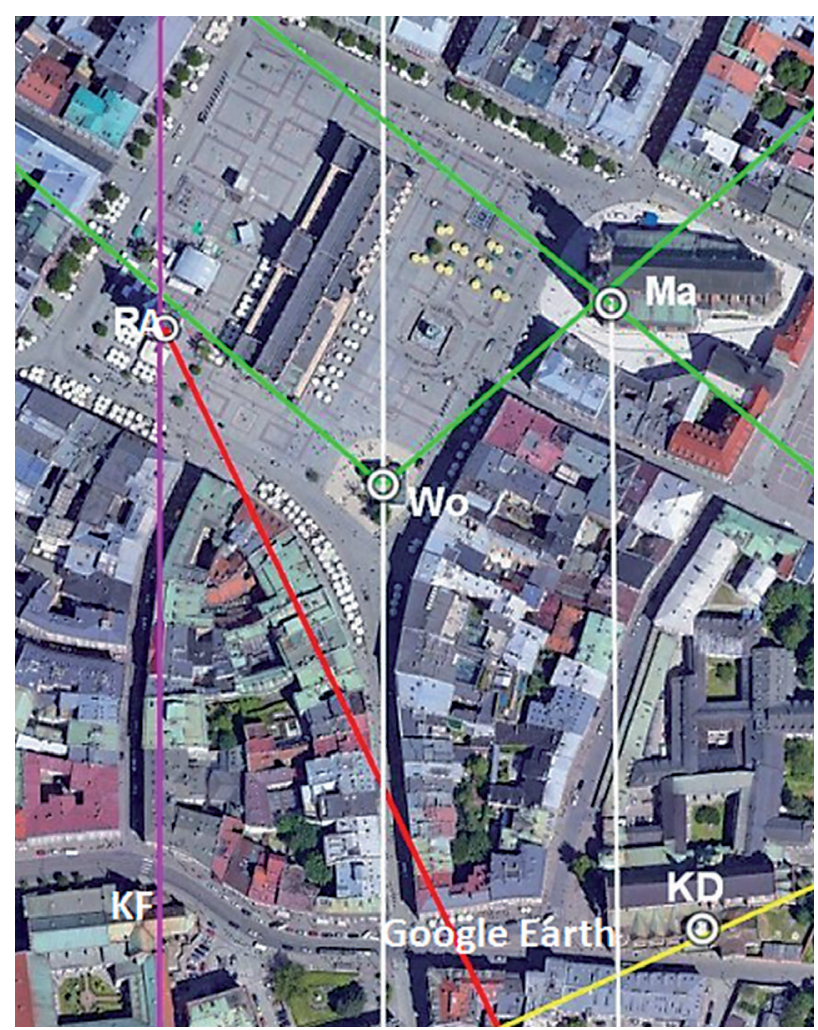

Fig. 20. St. Adalbert's Church - Wo (By W. Góral, J. Kudrys) Rys. 20. Kościół św. Wojciecha - Wo 


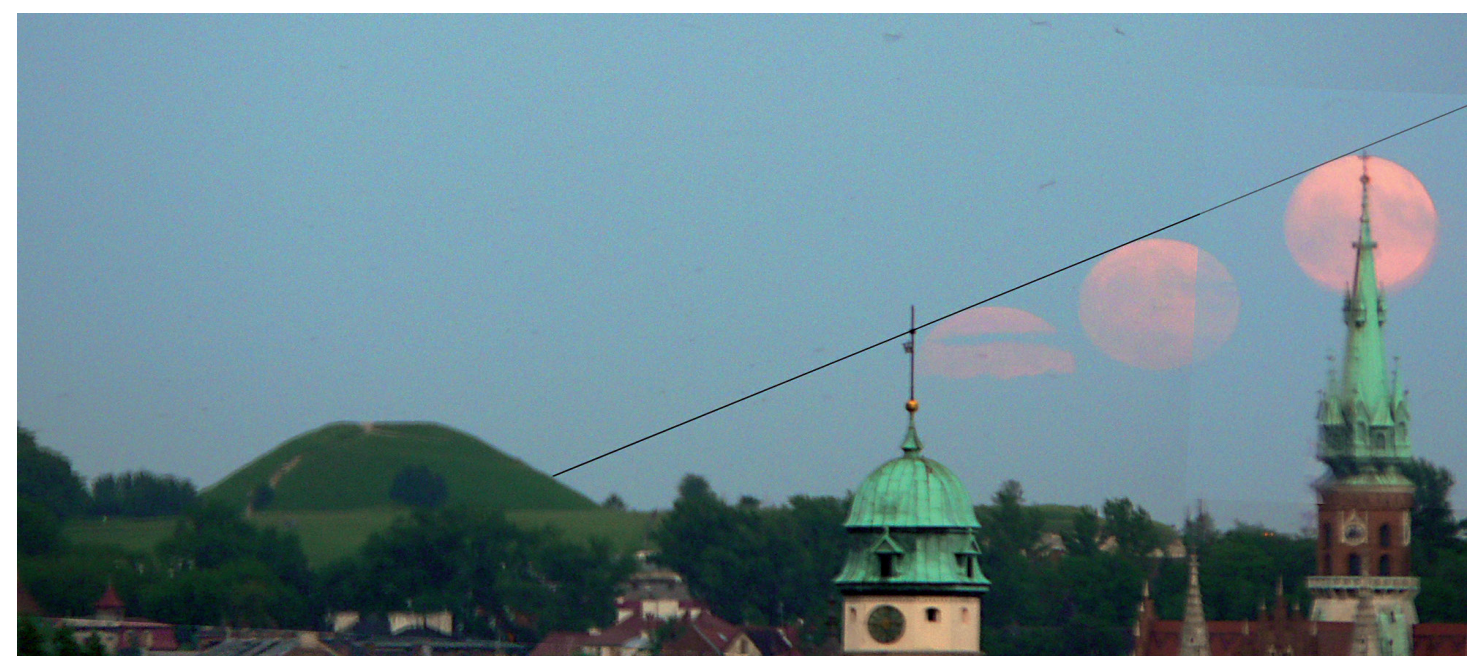

Fig. 21. Moonrise observed from Senatorska Tower on Wawel Hill on: June 27, 2007. Prepared by: W. Góral, J. Kudrys Rys. 21. Wschód Księżyca obserwowany obok Baszty Senatorskiej na Wzgórzu Wawelskim w dniu: 27-06-2007. Opr.: Góral W., Kudrys J.

stroyed after World War II during the construction of the WKS Wawel stadium. Based on old cadastral and military maps published in 1785-1905, its size and location were reproduced by P. Banasik (2010). The blue line in Fig. 19, was determined using the coordinates of the Esterka Mound and Krakus Mound. Its trace against the background of the Wawel Royal Castle is presented in Fig. 17. This line indicates the southernmost direction of the moonrise in a cycle of 18.61 years, (Góral, 2000). Recently, the Moon rise in the direction of KE - KK has been seen in years 2005-2007. Based on photos taken by the author on the Wawel Hill next to Senatorska Tower (27-06-2007), Fig. 21 was compiled. It represents the initial phase of the moonrise next to Krakus Mound. The last position of the Moon is in the background of the tower of St. Joseph's Church in the Podgórski Market Square.

\section{SACRAL MERIDIANS OF KRAKOW}

The author's attention was drawn to the meridian line defined by the position of St. Adalbert's Church (Fig. 20) located on the Main Square and the Pauline Church at Skałka, (5002'53.58', 1956'15.78"). When analyzing the line marked white it turned to run through Sanctuary of Divine Mercy $\left(50^{\circ} 01^{\prime} 11.70^{\prime \prime}\right.$, $19^{\circ} 56^{\prime} 15.78^{\prime \prime}$ ), and further east towards St. John Paul II Sanctuary. Also it turned out that the meridian line passes through the dome of this building and further runs exactly through the Town Hall Tower - RA, $\left(50^{\circ} 03^{\prime} 41.30^{\prime \prime}, 19^{\circ} 56^{\prime} 11.12^{\prime \prime}\right)$, located on the Main Square (Fig. 20). This line is marked purple, and is in figures: 17, 20, 24-29. An observer located near St. Adalbert's Church notes that the orientation of its rectangular part runs obliquely relative to the lines in the Main Market Square. It turns out that the walls of the rectangular part of the church indicate exactly eastwest and south-north. Towards noon this line runs initially along Grodzka Street (Fig. 23) and further to its west side, it crosses All Saints Square in the place where

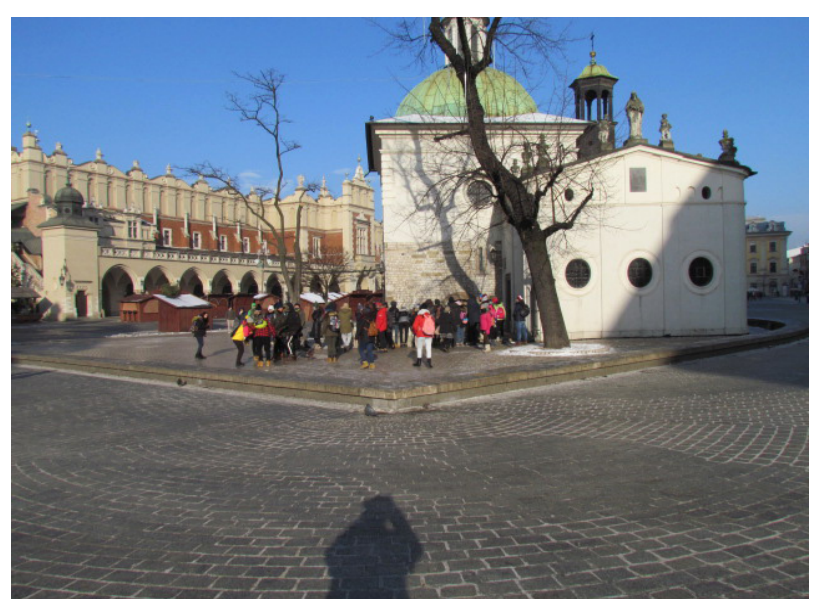

Fig. 22. St. Adalbert's Church. The photo was taken at the time of the upper sun culmination. Photo: W. Góral

Rys. 22. Kościół św. Wojciecha. Zdjęcie zostało wykonane w momencie kulminacji górnej Słońca 


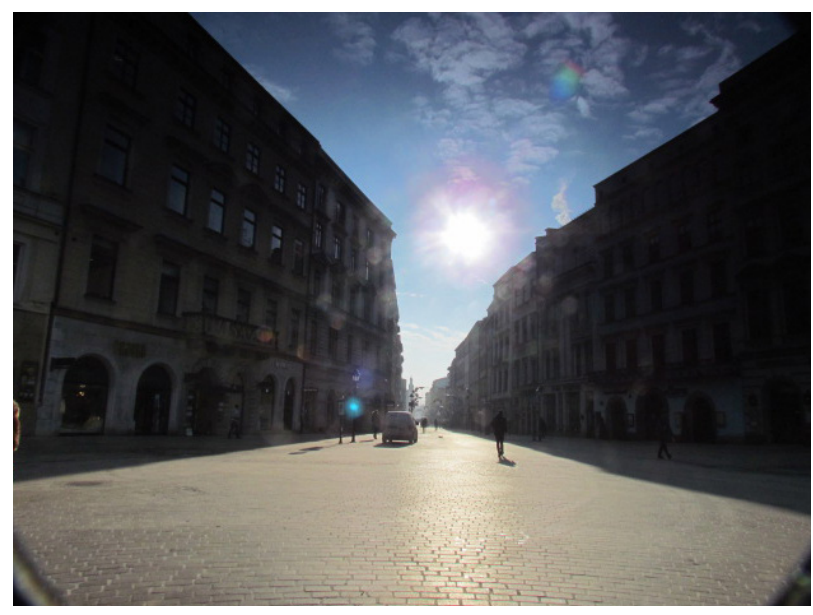

Fig. 23. Sun at the upper culmination on the meridian defined by the west wall of St. Adalbert Church. Photo: W. Góral Rys. 23. Słońce w kulminacji górnej na południku określonym przez zachodnią ścianę kościoła św. Wojciecha

the former All Saints' Church used to be. Nowadays there is a metal model of this church. Then this line runs through St. Magdalen's Square, the west side of the church of St. Giles, the eastern part of the slope of Wawel Hill, the southern part of the Bernardine church (Fig. 17), and further on runs through Skałka, Fig. 24). So an observer located in the place of St. Adalbert's Church, when Grodzka Street was not constructed yet, could easily determine the moment of noon based on the approaching sun to the slope line of the eastern part of the

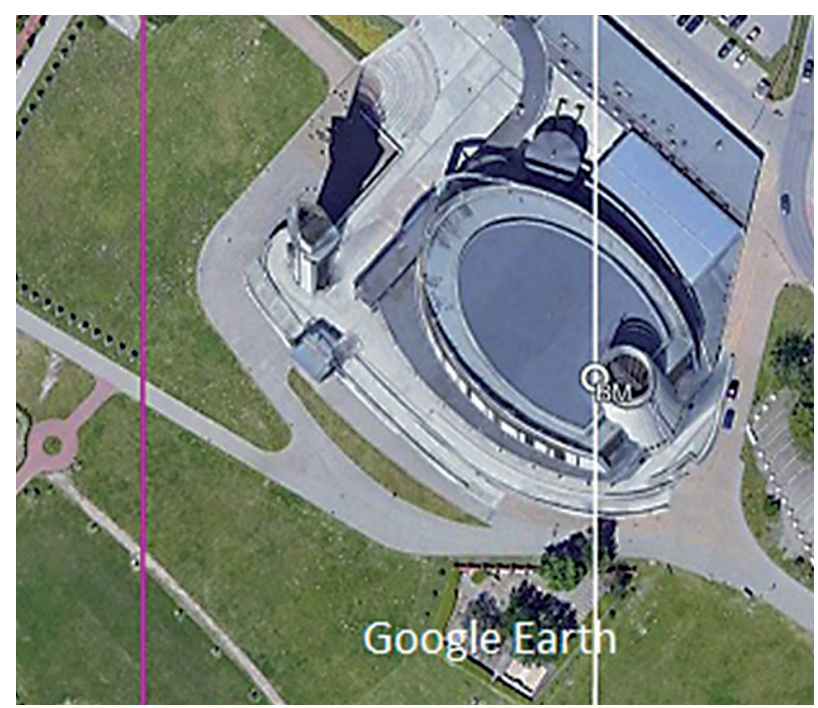

Fig. 25. The Sanctuary of Divine Mercy - BM Rys. 25. Bazylika Miłosierdzia Bożego - BM

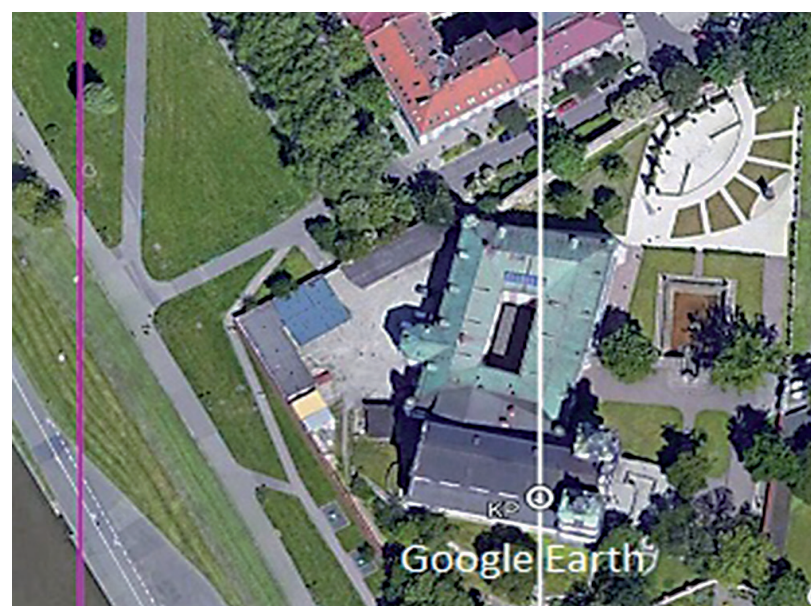

Fig. 24. Pauline Church - KP on Skałka.

Rys. 24. Kościół Paulinów - KP na Skałce

Wawel Hill and over the Skałka Hill. In turn the meridian marked in purple running south from the Town Hall Tower crosses the eastern part of the Franciscan Church and continues through the middle of the Wawel Hill.

.Extending from the church on Skałka the white line - to the author's surprise - runs further south, through the center of the Sanctuary of Divine Mercy in Lagiewniki, Fig. 25 and further east of Sanctuary of St. John Paul II,( 5000'47.51", 1956'11.12"), Fig. 26. We follow the meridian line to its intersection with the $50^{\circ}$ parallel, Fig. 27. In turn, extending from the St. Adalbert's church, we see a given line towards the

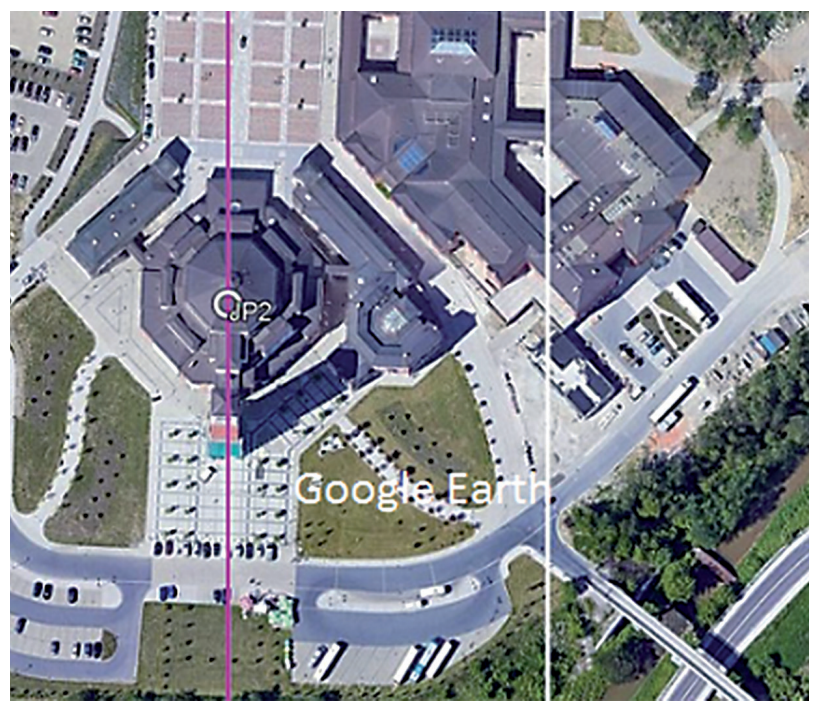

Fig. 26. Saint John Paul II Sanctuary - JP2

Rys. 26. Sanktuarium św. Jana Pawła II - JP2 


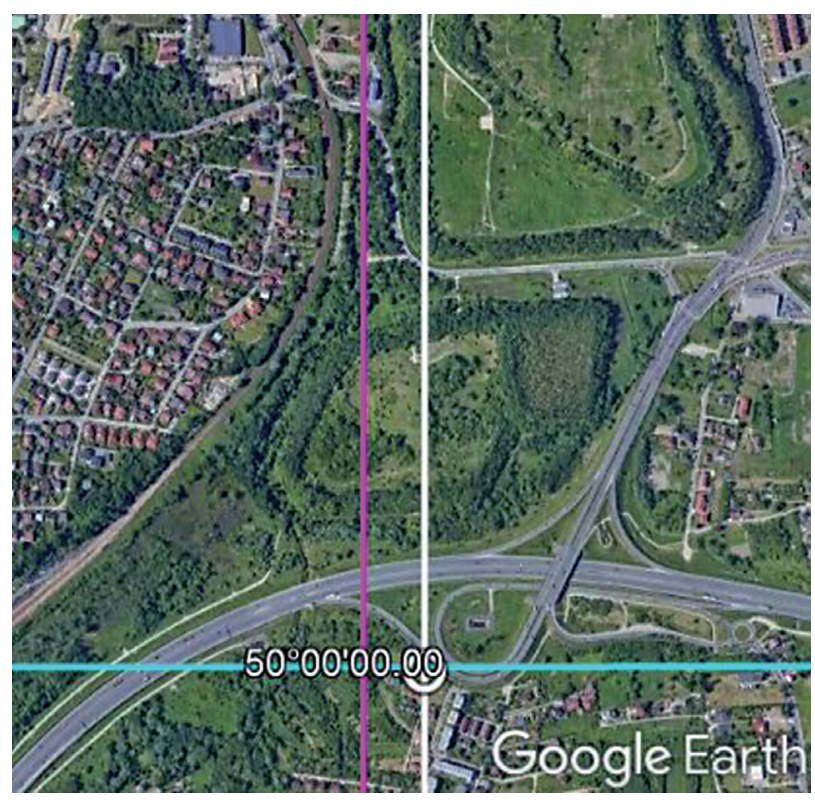

Fig. 27. Łagiewniki junction at the meridian $19^{\circ} 56^{\prime} 15.78^{\prime \prime}$ with the parallel $50^{\circ} 00^{\prime} 00.0$, (white line)

Rys. 27. Węzeł Łagiewnicki, punkt przecięcia południka $19^{\circ} 56^{\prime} 15.78^{\prime \prime} \mathrm{z}$ równoleżnikiem 5000’00,0” (linia biała)

north, which runs through the center of the chapel of St. Ann, 50 $04^{\prime} 22.18^{\prime \prime}, 19^{\circ} 56^{\prime} 15.78^{\prime \prime}$, located in the Helcels Social Care Center (DPS), (Fig. 28. and further through Fort Kleparz, $\left(50^{\circ} 04^{\prime} 30.44^{\prime \prime}, 19^{\circ} 56^{\prime} 15.8^{\prime \prime}\right)$, Fig. 29. The discussed meridian of east longitude with a value of $19^{\circ} 56^{\prime} 15.78^{\prime \prime}$ is marked on engravings in white.

\section{SUMMARY}

The location of Krakus Mound is very well integrated in the Krakow landscape. A fully open undulating horizon makes it easy to assign multiple dates, including the beginnings of individual seasons (Banasik, Góral 2016). The location of Krakus Mound in the relation to Wanda Mound defines the line of which we observe sunrises and sunsets twice a year. These days set four consecutive dates for division of a year into eight approximately equal parts. These dates must have been important for the old residents of Krakow, because they were coded inside Krakus Mound in the form of a central pole and radially running lines of pegs (fences) documented by R. Jamka, (1965). Based on the materials in the cited paper, it was possible to reproduce the layout precisely horizontal and all directions of sunrise and sunset given in Fig. 1 (Góral , 2018). It turns out

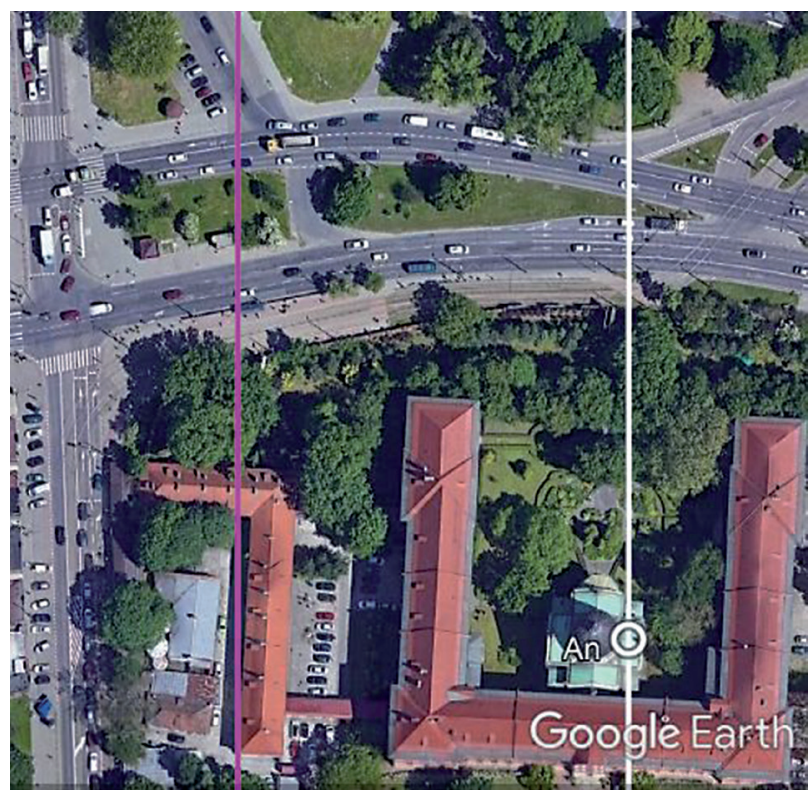

Fig. 28. St. Anne's Chapel at the Helcels Social Care Center - An

Rys. 28. Kaplica św. Anny, Dom Pomocy Społecznej im. Helclów - An

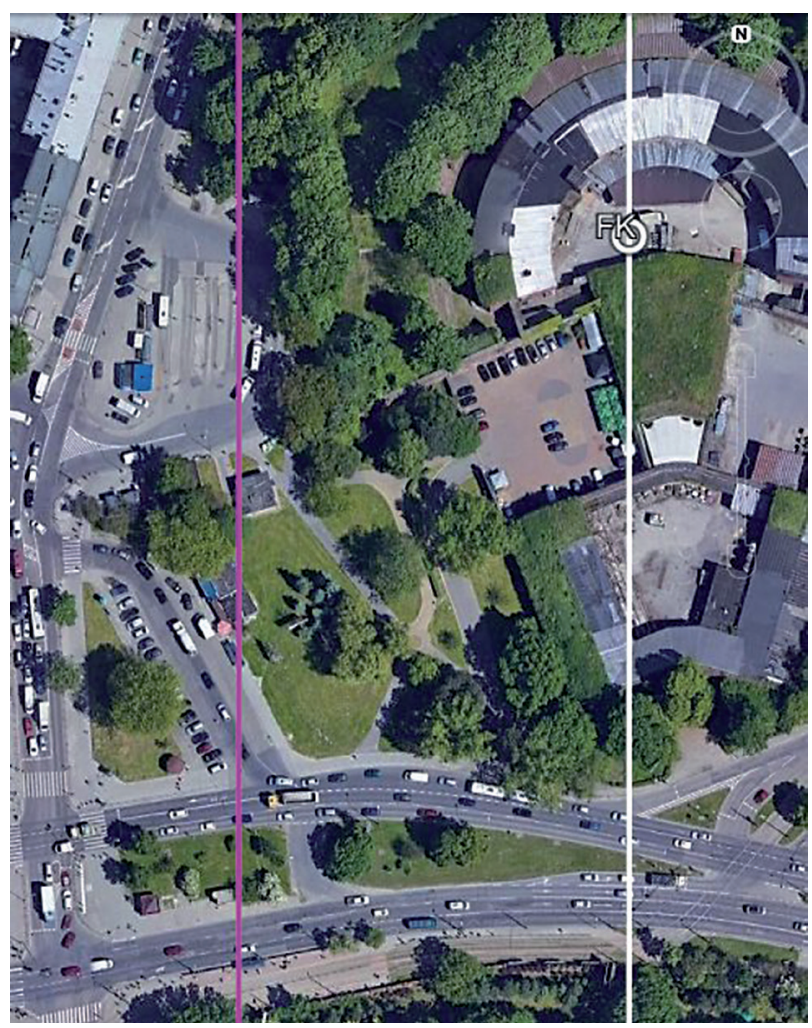

Fig. 29. Fort Kleparz - FK.

Rys. 29. Fort Kleparz - FK 
that there are also many churches and monasteries in the area of Krakow that have been located in all directions presented in Figure 1. The perfectly straight line of three Monasteries and one Convent runs from the Benedictine Abbey at Tyniec to the Lord's Ark at Nowa Huta. It is virtually parallel to the line of Krakus - Wanda Mounds. These lines form a corridor aligned to the direction of the rising Sun at the May Day, one of the most significant dates in the ancient calendar. The presented alignments of churches reflect the interaction between Earth and Sun.

\section{REFERENCES}

Banasik P. (2010). Lokalizacja kopca Esterki w świetle dawnych materiałów kartograficznych z obszaru Krakowa, Rocznik Krakowski t. LXXVI, Kraków, p. 35 - 44.
Banasik P., Góral W. (2016). Kopiec Krakusa a zachód Stońca $w$ dniu przesilenia letniego - aspekty astronomiczno-archeologiczne, Materiały Archeologiczne XLI, p. 301-312,

Wyd. Muzeum Archeologiczne w Krakowie.

Góral W. (2006). Aspekty geoinformatyczne i astronomiczne prehistorycznych kopców krakowskich i kopca Kraka w Krakuszowicach, Geodezja T. 12, z 2/1, UWND AGH, Kraków.

Góral W. (2018). Krakus and Wanda Mounds and the division of a year into eight parts, Geoinformatica Polonica, Vol. 17, Kraków, p.109-122.

Jamka R. (1965). Wyniki badań wykopaliskowych na kopcu Krakusa w Krakowie, Slavia Antiqua, T. XII, Warszawa-Poznań, p.183-233.

Kotlarczyk J. (1979). Celtyckie święta i kopce małopolskie, Z Otchłani Wieków, z. 2, 142-149.

Skorupa B. (1997). Wyznaczenie wspótrzędnych punktów niedostęnych na podstawie opracowania pomiarów klasycznych i sygnatów GPS, z uwzględnieniem wplywu odchylenia pionu, Geodezja T. 3, UWND AGH, Kraków, p. 47-51. 